\title{
Analysis of Inclusive Economic Development Index and Poverty in Aceh Province, Indonesia
}

\author{
Nurlina $^{1 *}$, Safuridar $^{2}$, Ziaul Maula $^{3}$ \\ 1, 2, 3 UNSAM, Langsa, Indonesia \\ *Corresponding author. Email: nurlina@unsam.ac.id
}

\begin{abstract}
Aceh Province is one of the regions in Indonesia that has an Inclusive Economic Development Index score of 5.55 and this is lower than the national figure of 5.75. However, Aceh is still in the satisfactory category. The purpose of this research is to analyze the effect of Poverty, Gini Ratio Index, Labor, Infrastructure and Human Development Index which directly influence Economic Growth in Aceh, and To analyze the effect of the Gini Ratio Index, Labor, Infrastructure, and Human Development Index indirectly. direct towards Inclusive Economic Development in Aceh through Economic Growth. The analytical method used is Path Analysis. The results of the study are Poverty Directly, the Gini Ratio Index has a negative and insignificant effect, Labor and Human Development Index has a positive and insignificant effect, Labor has a positive and significant effect, Infrastructure has a negative and significant effect, while the Human Development Index has a positive and insignificant effect. to Economic Growth in Aceh. Then, indirectly, the Poverty and Development Index have a negative and insignificant effect, the Gini Ratio Index, Infrastructure and Economic Growth have a negative and significant effect, while Labor has a positive and insignificant effect on the Inclusive Economic Development Index in Aceh.
\end{abstract}

Keywords: Economic growth, Inclusive economic development index, Gini ratio index, Poverty and HDI".

\section{INTRODUCTION}

Social inequality between individual regions that ends in poverty is a problem that is still faced by the state of Indonesia and other countries in the world. The problem of poverty and inequality of global income is shown by the presence of $20 \%$ of the world's population who are able to enjoy more than $70 \%$ of world income, in other words as many as $80 \%$ of the world's population only enjoy less than $30 \%$ of world income. The process of economic development really requires a high output increase and is also heavily influenced by economic growth. Based on data obtained from the Indonesian Central Statistics Agency (CSA) in 2019, Indonesia's economic growth is able to reduce poverty, unemployment, this can be seen from the decline in poverty from 2017 of $10,64 \%$ down to $9,82 \%$ with the rate of economic growth in 2017 amounted to 5,1\% and an increase in 2018 to $5,2 \%$.

To increase economic growth, the government has implemented various policies, one of which is the government implementing inclusive economic development. Inclusive economic development is one of
Indonesia's development agendas as stated in the Medium-Term Development Plan for 2020 to 2024. With an indicator known as the Inclusive Economic Development Index (IEDI). Aceh Province is one of the regions in Indonesia that has an Inclusive Economic Development Index score of 5,55 and this is lower than the national figure of 5,75. However, Aceh is still in the satisfactory category. Thus, Aceh Province still has the opportunity to increase the Inclusive Economic Development Index by utilizing the potential of natural resources in the Aceh region.

\subsection{Research Purposes}

The objectives of this study are as follows:

1. To analyze the effect of poverty directly on economic growth in Aceh Province.

2. To analyze the effect of the Gini Ratio Index Index directly on economic growth in Aceh Province.

3. To analyze the direct effect of labor on economic growth in Aceh Province. 
4. To analyze the effect of infrastructure directly on economic growth in Aceh Province.

5. To analyze the effect of the Human Development Index (HDI) directly on economic growth in Aceh Province.

6. To analyze the effect of economic growth directly on the inclusive economic development index in Aceh Province.

7. To analyze the indirect effect of poverty on the index of inclusive economic development in Aceh Province through economic growth.

8. To analyze the effect of the Gini Ratio Index indirectly on the index of inclusive economic development in Aceh Province through economic growth.

9. To analyze the indirect effect of labor on the index of inclusive economic development in Aceh Province through economic growth.

10. To analyze the indirect effect of infrastructure on the index of inclusive economic development in Aceh Province through economic growth.

11. To analyze the indirect effect of the Human Development Index (HDI) on the index of inclusive economic development in Aceh Province through economic growth.

\subsection{Research Urgency:}

This research is important to do to find out how much Inclusive Economic Development can reduce poverty, reduce inequality and be able to absorb labor in Aceh and how the direct and indirect effects of the inclusive economic development index on economic growth in Aceh, so that there are solutions and solutions to be made to alleviating poverty in Aceh.

\subsection{Inclusive Economic Growth}

McKinley (2010) and Ali and Zhuang (2009) from the Asian Development Bank have developed a conceptual framework to diagnose the development of a region whether it meets the criteria for inclusive growth. In the method used to measure the Indonesian Teacher Association of a country, the Asian Development Bank uses 35 indicators to determine the criteria for inclusive growth.

\subsection{Poverty}

According to the Central Statistics Agency (2018), poverty is the inability of an individual to meet the minimum basic needs for proper living. Another definition of poverty is a condition that is below the standard value line of minimum needs, both for food and non-food, which is called the poverty line or poverty threshold. The poverty line is the amount of rupiah needed by each individual to be able to pay for food needs equivalent to 2100 kilo calories per person per day and non-food needs consisting of housing, clothing, health, education, transportation and various other goods and services.

\subsection{Poverty Indicators}

One measurement tool that can be used to measure the level of poverty experienced by a person or group of people is the poverty indicator used by the National Development Planning Agency (Harniati, 2010). The poverty indicator in question is:

1. Food shortage, is a measure that looks at the adequacy of food and the quality of the food consumed. The size of this indicator is limited food stock, low calorie intake of the poor, and poor nutritional status of infants, children under five and mothers.

2. Limited access to health is a measure that looks at the limited access to health and the low quality of health services. Limited access to health can be seen from the difficulty in obtaining basic health services, the low quality of basic health services, the lack of reproductive services, the distance to health service facilities, the high costs of medical treatment and care. The poor generally tend to take advantage of health center services compared to hospitals.

3. Limited access to education. This indicator is measured by the quality of education available, the high cost of education, the limited educational facilities, the low opportunities for education.

4. Limited access to work. This indicator is measured by the limited opportunities for work and business, weak protection for business assets, wage differences, weak job protection, especially for child laborers and women workers.

5. Limited access to housing and sanitation services. The indicators used are the difficulty of having a healthy and livable house, and a healthy and decent residential environment.

6. Limited access to clean water. The indicators used are difficulty in obtaining clean water, limited control over water sources, and the low quality of water sources. Limited access to land. The indicators used are the structure of land ownership and control, uncertainty of ownership and land tenure. Access to land is a problem that affects farmer household life.

7. Limited access to natural resources. The indicators used are poor environmental 
conditions, low natural resources. This indicator is closely related to income originating from natural resources, such as rural areas, coastal areas and mining areas.

8. There is no guarantee of a sense of security, this indicator is related to insecure security in living both social and economic life.

9. Limited access to participation. This indicator is measured by the low involvement in policy making.

10. The size of the population burden, this indicator is related to the size of the family's dependents and the amount of pressure in life.

\subsection{Research Hypothesis}

The hypothesis in this study is as follows:

1. Poverty directly affects economic growth in Aceh Province.

2. The Gini Ratio Index has a direct effect on economic growth in Aceh Province.

3. Labor directly affects economic growth in Aceh Province.

4. Infrastructure directly affects economic growth in Aceh Province.

5. The Human Development Index (HDI) directly affects economic growth in Aceh Province.

6. Economic growth directly affects the inclusive economic development index in Aceh Province.

7. Poverty, indirectly affects the index of inclusive economic development in Aceh Province through economic growth.

8. The Gini Ratio Index Index indirectly affects the index of inclusive economic development in Aceh Province through economic growth.

9. Labor indirectly affects the index of inclusive economic development in Aceh Province through economic growth.

10. Infrastructure indirectly affects the inclusive economic development index in Aceh Province through economic growth.

11. The Human Development Index (HDI) indirectly affects the inclusive economic development index in Aceh Province through economic growth.

\section{METHOD}

To determine the direct effect of job opportunities, infrastructure, and HDI on Economic Growth and the Inclusive Economic Development Index, as well as the indirect effect on the Inclusive Economic Development Index on economic growth, is to use the Path Analysis analysis tool. The structural equation be:

Sub structural equation model I :

$\mathrm{Y} 1=\beta \mathrm{Y}_{1} \mathrm{X}_{1}+\beta \mathrm{Y}_{1} \mathrm{X}_{2}+\beta \mathrm{Y}_{1} \mathrm{X}_{3}+\beta \mathrm{Y}_{1} \mathrm{X}_{4}+\beta \mathrm{Y}_{1} \mathrm{X}_{5}+\varepsilon_{1}$ (1)

Sub structural equation model II :

$\mathrm{Y} 2=\beta \mathrm{Y}_{2} \mathrm{X}_{1}+\beta \mathrm{Y}_{2} \mathrm{X}_{2}+\beta \mathrm{Y}_{2} \mathrm{X}_{3}+\beta \mathrm{Y}_{2} \mathrm{X}_{4}+\beta \mathrm{Y}_{2} \mathrm{X}_{5}+$

$\beta \mathrm{Y}_{2} \mathrm{Y}_{1}+\varepsilon_{1}$

Description :

$\mathrm{Y}_{1} \quad$ : Economic growth

$\mathrm{Y}_{2} \quad$ : Inclusive Economic Development Index

$\beta \quad$ : Regression Coefficient

$\mathrm{X}_{1} \quad$ : Poverty

$\mathrm{X}_{2} \quad$ : Gini Ratio Index

$\mathrm{X}_{3}$ : Labor

$\mathrm{X}_{4} \quad$ : Infrastructur

$\mathrm{X}_{5} \quad$ : Human Development Index $\varepsilon$ : Term of Error

\section{RESULTS AND DISCUSSION}

The Inclusive Economic Development Index in 23 (Twenty Three) Districts / Cities in the last 7 (seven) years, it can be seen that of all the districts / cities in Aceh Province Banda Aceh City has the highest Inclusive Economic Development Index value compared to other regions. in Aceh Province. When viewed from the figures from year to year the index of inclusive economic development continues to increase, from 2013 to 6,05 increasing to 6,43 in 2019. The economic development index value in Banda Aceh City is a very good value because of the development index value. the inclusive economy in Banda Aceh City is higher than the national development index figure. For the inclusive economic development index, Banda Aceh City is also included in no. 7 (seven) of the 10 (ten) highest ranking in Indonesia.

After Banda Aceh City, the next region which also has an index of inclusive economic development in Aceh is Lhokseumawe City, which was 5,62 in 2013 and increased to 5,91 in 2019. Then the next city is the Langsa City area with an inclusive economic development index of 5,45 in 2013 and increased to 5,82 in 2019. Of the 23 (twenty three) districts of East Aceh, it is the region that has the lowest inclusive development index in Aceh. The following is a graph of the Inclusive Development Index by Regency / City in Aceh province in 2019. 


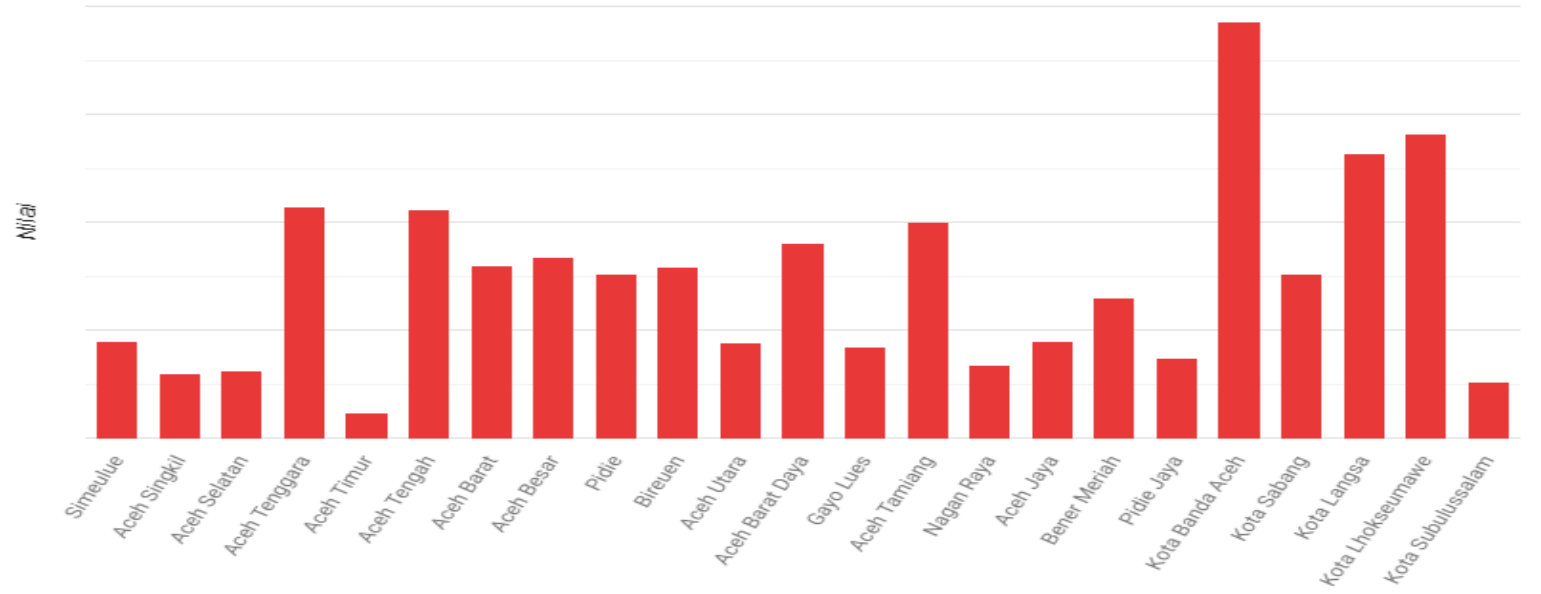

Figure 1. Inclusive Development Index by Regency / City in Aceh Province in 2019

\subsection{Explanation}

indirect effect and the total effect can be seen in Table 1

Direct Effect, Indirect Effect dan Total Effect The

calculations for the analysis of the direct effect, the

Table 1 Results of Direct Effect, Indirect Effect and Total Effect Between Variables

\begin{tabular}{|c|c|c|c|}
\hline \multirow{2}{*}{$\begin{array}{c}\text { Relationship } \\
\text { Variable }\end{array}$} & Direct & Influence & \multirow{2}{*}{ Total } \\
\cline { 2 - 4 } & $-0,673$ & - & $-0,673$ \\
\hline $\mathrm{X}_{1} \rightarrow \mathrm{Y}_{1}$ & $-0,027$ & - & $-0,027$ \\
\hline $\mathrm{X}_{2} \rightarrow \mathrm{Y}_{1}$ & 0,709 & - & 0,709 \\
\hline $\mathrm{X}_{3} \rightarrow \mathrm{Y}_{1}$ & $-0,064$ & $-0,064$ \\
\hline $\mathrm{X}_{4} \rightarrow \mathrm{Y}_{1}$ & 0,520 & 0,792 & 0,520 \\
\hline $\mathrm{X}_{5} \rightarrow \mathrm{Y}_{1}$ & $-0,683$ & 0,032 & 0,109 \\
\hline $\mathrm{X}_{1} \rightarrow \mathrm{Y}_{2}$ & $-2,076$ & $-0,835$ & $-2,044$ \\
\hline $\mathrm{X}_{2} \rightarrow \mathrm{Y}_{2}$ & 1,275 & 0,075 & 0,440 \\
\hline $\mathrm{X}_{3} \rightarrow \mathrm{Y}_{2}$ & $-0,208$ & $-0,612$ & $-0,133$ \\
\hline $\mathrm{X}_{4} \rightarrow \mathrm{Y}_{2}$ & $-0,850$ & - & $-1,462$ \\
\hline $\mathrm{X}_{5} \rightarrow \mathrm{Y}_{2}$ & $-1,177$ & & $-1,177$ \\
\hline $\mathrm{Y}_{1} \rightarrow \mathrm{Y}_{2}$ & & -12 & \\
\hline
\end{tabular}

Source: Research Results (2020)

Based on table 1 it can be explained as follows:

1. Direct Effect

a. The influence of the poverty variable on economic growth is $-0,673$.

b. The effect of the Gini Ratio Index variable on economic growth is $-0,027$.

c. The influence of the labor variable on economic growth is 0,709 .

d. The influence of the infrastructure variable on economic growth is $-0,064$.

e. The influence of the human development index variable on economic growth is 0,520 . as follows:

f. The influence of the poverty variable on the inclusive economic development index is $-0,683$.

g. The effect of the Gini Ratio Index variable on the inclusive economic development index is 2,076.

h. The effect of the labor variable on the inclusive economic development index is 1,275.

i. The influence of the infrastructure variable on the inclusive economic development index is 0,208 . 
j. The influence of the human development index variable on the inclusive economic development index is $-0,850$.

$\mathrm{k}$. The influence of the economic growth variable on the inclusive economic development index is $-1,177$.

\section{Indirect Effect}

a. The influence of the poverty variable on the index of inclusive economic development through economic growth is 0,792 .

b. The influence of the Gini Ratio Index variable variable on the inclusive economic development index through economic growth is 0,032 .

c. The influence of the labor variable on the index of inclusive economic development through economic growth is $-0,835$.

d. The influence of the infrastructure variable on the inclusive economic development index through economic growth is 0,075 .

e. The influence of the human development index variable on the inclusive economic development index through economic growth is $-0,612$. a. The total influence of the poverty variable on the inclusive economic development index through economic growth is 0,109 .

b. The total influence of the Gini Ratio Index variable variable on the inclusive economic development index through economic growth is 2,044 .

c. The total effect of the labor variable on the inclusive economic development index through economic growth is 0,440 .

d. The total effect of the infrastructure variable on the inclusive economic development index through economic growth is $-0,133$.

e. The total effect of the human development index variable on the inclusive economic development index through economic growth is $-1,462$.

The amount of error value in each of the effects of the independent variable on the dependent is obtained through the following calculations:

$$
\begin{aligned}
& \beta \mathrm{e}_{1}=1-0,9106=0,0894=0,089 \\
& \beta \mathrm{e}_{2}=1-0,8451=0,1549=0,155
\end{aligned}
$$

\section{Total Effect}

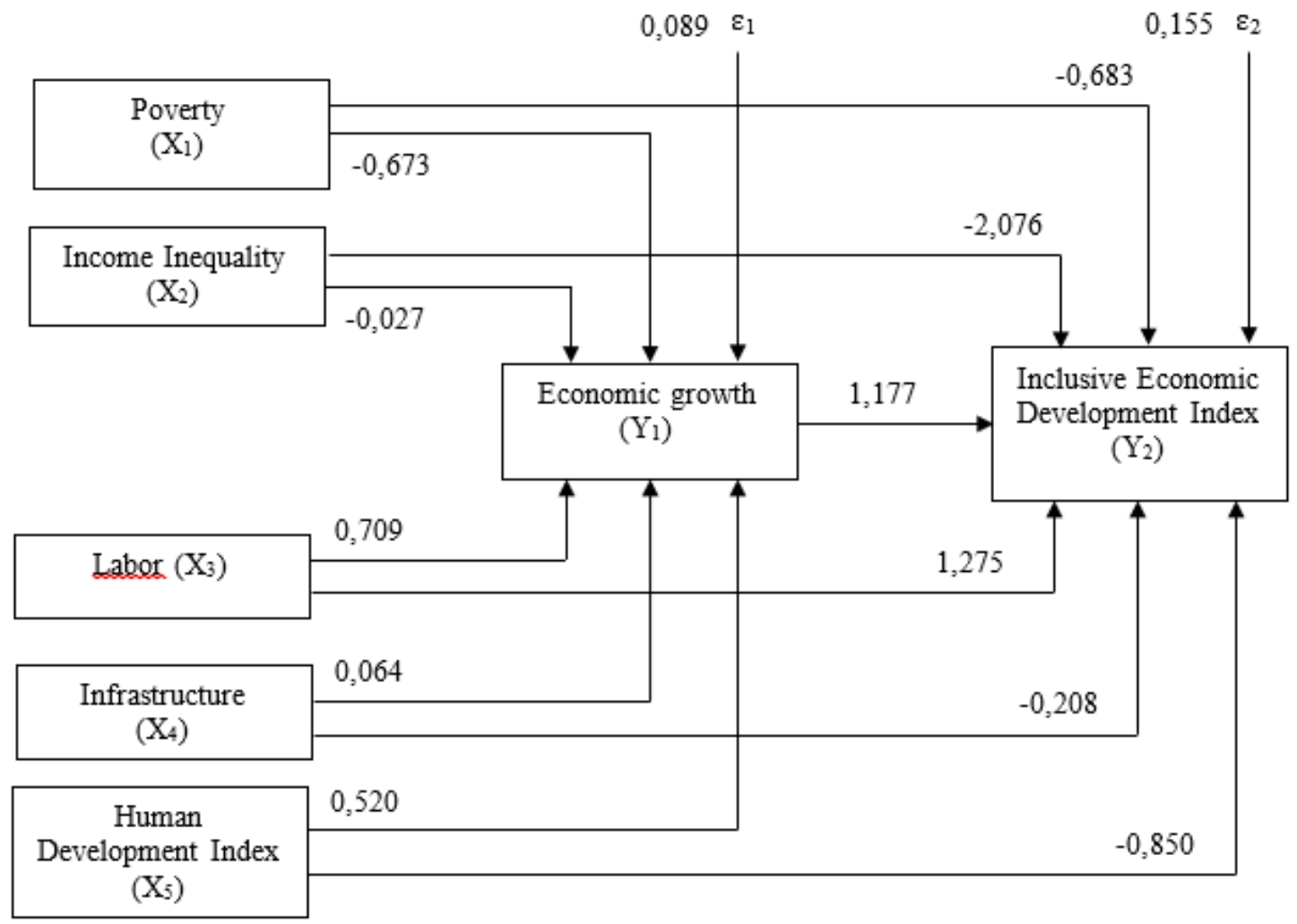

Figure 2 Structural equation model

Based on the research results, the relationship between variables is formed by the path analysis 
coefficient model. The substructure equation can be a model for the path analysis coefficient, which is as follows:

Sub Structural Equations I :

$\mathrm{Y}_{1}=-0,673 \mathrm{Y}_{1} \mathrm{X}_{1}-0,027 \mathrm{Y}_{1} \mathrm{X}_{2}+0,709 \mathrm{Y}_{1} \mathrm{X}_{3}-0,064 \mathrm{Y}_{1} \mathrm{X}_{4}$ $+0,520 \mathrm{Y}_{1} \mathrm{X}_{5}+0,089 \varepsilon_{1}$

Sub Structural Equations II :

$\mathrm{Y}_{2}=-0,683 \mathrm{Y}_{2} \mathrm{X}_{1}-2,076 \mathrm{Y}_{2} \mathrm{X}_{2}+1,275 \mathrm{Y}_{2} \mathrm{X}_{3}-0,208 \mathrm{Y}_{2} \mathrm{X}_{4}$ $-0,850 \mathrm{Y}_{2} \mathrm{X}_{5}-1,177 \mathrm{Y}_{2} \mathrm{Y}_{1}+0,155 \varepsilon_{2}$

In the trimming theory, testing the validity of the research model is observed by calculating the total coefficient of determination as follows:

$$
\begin{aligned}
\mathrm{Rm}^{2} & =1-\left(0,0894^{2}\right)\left(0,1549^{2}\right) \\
& =1-(0,00799236)(0,02399401) \\
& =1-0,000192 \\
& =0,9998 \\
& =99,98 \%
\end{aligned}
$$

The coefficient of determination of 0,998 shows that $99,98 \%$ of the information contained in the data can be explained by the model, while the remaining $0,02 \%$ is explained by errors and other variables outside the model. The coefficient in this model is relatively large so it deserves further interpretation.

\subsection{Discussion \\ 3.2.1. The Direct Effect of Poverty on Economic Growth in Aceh Province}

The first hypothesis statement states that poverty directly has a significant effect on economic growth in Aceh Province. The magnitude of the influence of poverty on economic growth is $-0,673$ with a significant value on prob. $0,1721>\alpha=0,05$, the hypothesis in this study was rejected. Thus, it can be concluded that poverty does not directly affect economic growth in Aceh Province. If there is an increase in poverty by 1 percent, then economic growth in Aceh Province will decrease insignificantly by 0,673 percent, assuming other variables are constant.

Poverty is one of the problems that has become the center of attention of the government, various programs carried out by the government to reduce the poverty rate have not produced significant results. Economic growth is believed to have a significant influence in reducing the number of poverty, but the effect of economic growth cannot completely solve the problem of poverty. Poverty alleviation requires quality and equitable economic growth. Quality economic growth, namely economic growth in favor of the community through the development of the industrial and agricultural sectors which has a very strong influence in reducing poverty (Siregar and Wahyuniarti: 2012). The results of this study are in accordance with research conducted by Pratama and Darsana (2019), Rahmadi and Parmadi
(2019) which state that poverty has a negative effect on economic growth.

\subsubsection{The Direct Effect of the Gini Ratio Index on Economic Growth in Aceh Province}

The second hypothesis statement which states that the Gini Ratio Index directly has a significant effect on economic growth in Aceh Province. The magnitude of the influence of the Gini Ratio Index on economic growth is $-0,027$ with a significant value on prob. $0,9400>\alpha=0,05$, the hypothesis in this study was rejected. Thus, it can be concluded that the Gini Ratio Index does not directly have a significant effect on economic growth in Aceh Province. If there is an increase in the Gini Ratio Index by 1 percent, then economic growth in Aceh Province will decrease insignificantly by 0,027 percent, assuming other variables are constant.

Kuznets (in Amri, 2017) states that the relationship between economic growth and the U-shaped Gini Ratio Index is inverted, where initially an increase in economic growth can increase the Gini Ratio Index. After reaching certain conditions, an increase in income actually lowers the Gini Ratio Index. Economic growth without the availability of job opportunities will not create an even distribution of income. The results of this study are consistent with research conducted by Rahmadi and Parmadi (2019) which states that the Gini Ratio Index has a negative effect on economic growth.

\subsubsection{The Direct Effect of Labor on Economic Growth in Aceh Province}

The third hypothesis statement states that labor directly has a significant effect on economic growth in Aceh Province. The magnitude of the influence of labor on economic growth amounted to 0,709 with a significant value on prob. $0,0167<\alpha=0,05$, the hypothesis in this study is accepted. Thus it can be concluded that the workforce directly has a significant effect on economic growth in Aceh Province. If there is an increase in the workforce of 1 percent, then economic growth in Aceh Province will increase significantly by 0,709 percent, assuming other variables are constant.

Labor is one of the important factors of production in an economy. Because the productivity of other production factors is very dependent on the productivity of labor in producing production. One way to increase output is to increase the number of workers. However, an increase in the number of workers must be balanced with an increase in the amount of capital and technology so that economic growth will continue to increase. The results of this study are in accordance with research conducted by Dewi and Idris (2019), Purnamasari, 
Rostin and Ernawati (2017) who say that labor has a positive effect on economic growth in Southeast Sulawesi Province.

\subsubsection{The Direct Influence of Infrastructure on Economic Growth in Aceh Province}

The fourth hypothesis statement states that infrastructure directly has a significant effect on economic growth in Aceh Province. The magnitude of the influence of infrastructure on economic growth is 0,064 with a significant value on prob. $0,099>\alpha=0,05$, the hypothesis in this study is rejected. Thus it can be concluded that infrastructure does not directly affect economic growth in Aceh Province. If there is an increase in infrastructure by 1 percent, then economic growth in Aceh Province will decrease insignificantly by 0,064 percent, assuming that other variables are constant.

Infrastructure development is needed in an effort to increase economic growth in a region. With the infrastructure, it is hoped that it can facilitate people's economic activities so that they can increase productivity and community income. The reason is that infrastructure has a negative effect on economic growth. Infrastructure development in Aceh is carried out in stages, so that it does not have a direct impact on economic growth. The results of this study are in accordance with research conducted by Handayani, Susetyo and Saleh (2017) who say that infrastructure has a negative effect on Gross Domestic Product in South Sumatra Province.

\subsubsection{The Effect of the Human Development Index Directly on Economic Growth in Aceh Province}

The fifth hypothesis statement which states that the human development index directly has a significant effect on economic growth in Aceh Province. The magnitude of the influence of the human development index on economic growth is 0,520 with a significant value on prob. $0,416>\alpha=0,05$, the hypothesis in this study was rejected. Thus it can be concluded that the human development index does not directly have a significant effect on economic growth in Aceh Province. If there is an increase in the human development index by 1 percent, then economic growth in Aceh Province will increase insignificantly by 0,520 percent, assuming other variables are constant.

The human development index is an important indicator to measure the quality of human life, both in terms of health, education level and decent living standards. The more human development increases, the economic growth will achieve increased productivity and job opportunities. The results of this study are in accordance with research conducted by Asnidar (2018), Handayani, Susetyo and Saleh (2017), Rakhmamawati (2016) which states that the human development index has a positive effect on economic growth.

\subsubsection{The Direct Effect of Economic Growth on the Inclusive Economic Development Index in Aceh Province}

The sixth hypothesis statement which states that economic growth directly has a significant effect on the inclusive economic development index in Aceh Province. The magnitude of the effect of economic growth on the inclusive economic development index is $-1,177$ with a significant value on prob. 0,0904> $\alpha=$ 0,05 , the hypothesis in this study is rejected. Thus it can be concluded that economic growth directly does not have a significant effect on the index of inclusive economic development in Aceh Province. If there is an increase in economic growth of 1 percent, the inclusive economic development index in Aceh Province will increase insignificantly by 1,177 percent, assuming other variables are constant.

Inclusive economic growth is a growth process that ensures prosperous access to economic opportunities for all social segments regardless of the circumstances of each individual (Ali and Zhuang: 2007). Development that only makes the aspect of economic growth the only achievement, so that sometimes high economic growth occurs without equal distribution of welfare which results in high unemployment.

\subsubsection{The Indirect Effect of Poverty on the Inclusive Economic Development Index in Aceh Province through Economic Growth}

The seventh hypothesis statement which states that poverty indirectly has a significant effect on the index of inclusive economic development in Aceh Province through economic growth. The magnitude of the indirect effect of poverty on the index of inclusive economic development through economic growth is 0,792 with a significant value on prob. 0,3284> $\alpha=0,05$, the hypothesis in this study was rejected. Thus it can be concluded that poverty does not indirectly have a significant effect on the index of inclusive economic development in Aceh Province through economic growth.

High economic growth does not guarantee that everyone will get the same benefits. Uneven development will lead to high unemployment and 
poverty rates, which will decrease people's purchasing power, thus entering a vicious cycle of poverty. According to Nurske (in Prasetyoningrum and Sukmawati: 2018) the vicious circle of poverty illustrates that the causes of poverty are low savings, low investment, lack of capital, low productivity, low income which results in low savings and so on.

\subsubsection{The Indirect Effect of the Gini Ratio Index on the Inclusive Economic Development Index in Aceh Province through Economic Growth}

The eighth hypothesis statement which states that the Gini Ratio Index has a significant effect on the index of inclusive economic development in Aceh Province through economic growth. The magnitude of the effect of the Gini Ratio Index indirectly on the index of inclusive economic development through economic growth is 0,032 with a significant value on prob. 0,0065 $<\alpha=0,05$, the hypothesis in this study is accepted. Thus it can be concluded that the Gini Ratio Index indirectly has a significant effect on the index of inclusive economic development in Aceh Province through economic growth.

High economic growth is one indicator of the success of national development. In addition, the development of a region is also determined by the region's ability to reduce poverty and unemployment and can reduce the Gini Ratio Index. This is because a high Gini Ratio Index can hamper the rate of economic growth and a sustainable development process.

\subsubsection{The Indirect Effect of Labor on the Inclusive Economic Development Index in Aceh Province through Economic Growth}

The eighth hypothesis statement which states that labor indirectly has a significant effect on the index of inclusive economic development in Aceh Province through economic growth. The magnitude of the indirect influence of labor on the index of inclusive economic development through economic growth is $-0,835$ with a significant value on prob. $0,0456<\alpha=0,05$, the hypothesis in this study is accepted. Thus, it can be concluded that labor has a significant indirect effect on the index of inclusive economic development in Aceh Province through economic growth.

The main strategy for realizing inclusive economic development is the creation and expansion of productive and profitable jobs as well as full support for the development of micro, small and medium enterprises (MSMEs) so that they can absorb more labor.

\subsubsection{The Indirect Influence of Infrastructure on the Inclusive Economic Development Index in Aceh Province through Economic Growth}

The ninth hypothesis statement which states that infrastructure indirectly has a significant effect on the index of inclusive economic development in Aceh Province through economic growth. The magnitude of the indirect effect of infrastructure on the index of inclusive economic development through economic growth is 0,075 with a significant value on prob. 0,0150 $<\alpha=0,05$, the hypothesis in this study is accepted. Thus it can be concluded that infrastructure indirectly has a significant effect on the index of inclusive economic development in Aceh Province through economic growth.

Infrastructure is a prerequisite for other sectors to develop and also a means of creating relationships with one another. Empowerment of resources to build infrastructure for economic processes, resulting in a multiplication of economic and social impacts (Setiadi, in Warsilan and Noor: 2015).

\subsubsection{The Indirect Effect of the Human Development Index on the Inclusive Economic Development Index in Aceh Province through Economic Growth.}

The tenth hypothesis statement which states that the human development index indirectly has a significant effect on the index of inclusive economic development in Aceh Province through economic growth. The magnitude of the indirect effect of the human development index on the index of inclusive economic development through economic growth is $-0,612$ with a significant value on prob. 0,0904> $\alpha=0,05$, the hypothesis in this study is rejected.

Thus it can be concluded that the human development index does not indirectly have a significant effect on the index of inclusive economic development in Aceh Province through economic growth. The human development index has three dimensions, one of which is that the level of education in Aceh Province is getting higher, but not accompanied by adequate employment opportunities. So it cannot reduce the unemployment rate, but the higher the level of education the higher the unemployment rate.

\section{CONCLUSION}

1. Poverty directly has a significant effect on economic growth in Aceh Province. The magnitude of the influence of poverty on economic growth is $-0,673$ 
2. The Gini Ratio Index has a significant direct effect on economic growth in Aceh Province. The magnitude of the influence of the Gini Ratio Index on economic growth is $-0,027$

3. Manpower directly has a significant effect on economic growth in Aceh Province. The magnitude of the influence of labor on economic growth is 0,709

4. Infrastructure directly has a significant effect on economic growth in Aceh Province. The magnitude of the influence of infrastructure on economic growth is $-0,064$

5. The Human Development Index (HDI) has a significant effect on the inclusive economic development index in Aceh Province. The magnitude of the effect of economic growth on the inclusive economic development index is 1,177

6. Economic growth does not directly have a significant effect on the inclusive economic development index in Aceh Province. The magnitude of the influence of economic growth on the inclusive economic development index is $-0,850$

7. Poverty indirectly has a significant effect on the index of inclusive economic development in Aceh Province through economic growth. The magnitude of the indirect effect of poverty on the index of inclusive economic development through economic growth is 0,792

8. The Gini Ratio Index has a significant indirect effect on the index of inclusive economic development in Aceh Province through economic growth. The magnitude of the indirect effect of income inequality on the index of inclusive economic development through economic growth is 0,032

9. Labor indirectly has a significant effect on the index of inclusive economic development in Aceh Province through economic growth. The magnitude of the indirect influence of labor on the index of inclusive economic development through economic growth is $-0,835$

10. Infrastructure indirectly has a significant effect on the index of inclusive economic development in Aceh Province through economic growth. The magnitude of the indirect effect of infrastructure on the index of inclusive economic development through economic growth is 0,075

11. The human development index indirectly has a significant effect on the index of inclusive economic development in Aceh Province through economic growth. The magnitude of the indirect effect of the human development index on the index of inclusive economic development through economic growth is 0,612

\section{REFERENCES}

[1] Ali, I. And J. Zhuang. 2007. Inklusif Growth Toward a Prosperous Asia : Policy Implications. ERD Working Paper Series, No. 97. Manila: ADB.

[2] Amri, Khairul. 2017. Analisis Pertumbuhan Ekonomi dan Indeks Rasio Gini : Panel Data 8 Provinsi di Sumatera. Jurnal Ekonomi Manajemen dan Teknologi Vol.1, No.1.

[4] Asnidar. 2018. Pengaruh Indeks Pembangunan Manusia dan Inflasi terhadap pertumbuhan Ekonomi di Kabupaten Aceh Timur. Jurnal Samudra Ekonomika, Vol. 2, No.1.

[5] Badan Pusat Statistik Aceh ,2019. Jumlah Penduduk Miskin di Aceh

[6] Badan Pusat Statistik Aceh ,2018.

[7] Dewi, Endang Putri dan Idris. 2019. Pengaruh Tenaga Kerja, Migrasi Masuk dan Pembangunan Manusia terhadap Pertumbuhan Ekonomi di Indonesia. Jurnal Kajian ekonomi Pembangunan UNP, Vol. 1, No. 2.

[8] Handayani, Tino, Didik Susetyo dan M. Syirod Saleh. 2017. Pengaruh Belanja Modal, Infrastruktur dan Indeks Pembangunan Manusia terhadap Produk Domestik Regional Bruto di Provinsi Sumatera Selatan. Jurnal Ekonomi Pembangunan, Vol. 15, No.2.

[9] Laporan Perekonomian Provinsi Aceh, 2020. PDRB Menurut Lapangan Usaha Berdasarkan Harga Konstan Tahun 2019

[10]Nurlina dan ARB.Ginting, 2018. Analisis Identifikasi Pusat-pusat Pertumbuhan dan Wilayah Pendukungnya Dalam Pengembangan Wialyah Aceh, Jurnal Samudra Ekonomi dan Bisnis, Vol.9 (1): $60-69$

[11]Nurlina. Hanum Nurlaila, Muda I dan Safuridar,2019. Analysis of Structural Poverty Trend Among Rice farmers in East Aceh Regency, Indonesia, Journal Global Business and Review, Vol.24 (1): 71-79

[12] Sulia. 2018. Analisis Pengaruh Indeks Pembangunan Manusia (IPM), Pertumbuhan Ekonomi dan pengangguran terhadap Kemiskinan di Indonesia. EKUILIBRIUM: Jurnal Ekonomi Syariah, Vol.6 (2): 217-240. 
[13] Pratama, AA Gede Krisna dan Darsana Ida Bagus. 2019. Pengaruh Kemiskinan dan Investasi terhadap Pertumbuhan Ekonomi dan kesejahteraan Masyarakat. E-Jurnal Ekonomi Pembangunan Universitas Udayana. Vol. 8 No. 6.

[14] Purnamasari, Sri Ayui, Rostin dan Ernawati. 2017. Peangaruh Investasi dan Tenaga Kerja terhadap Pertumbuhan Ekonomi di Provinsi Sulawesi Tenggara. Jurnal Progres Ekonomi Pembangunan. Vol. 2, No. 2.

[15] Rahmadi, Slamet dan Parmadi. 2019. Pengaruh Indeks Rasio Gini dan Kemiskinan terhadap Pertumbuhan Ekonomi antar Pulau di Indonesia. Jurnal Paradigma Ekonomika. Vol. 14, No.2.
[16] Rakhmawati, Rusmarinda. 2016, Pengaruh Indeks Pembangunan Manusia (IPM), Tenaga Kerja, dan Pendidikan terhadap Pertumbuhan Ekonomi di Provinsi Jawa Tengah, Naskah Publikasi. Fakultas Ekonomi dan Bisnis. Universitas Muhammadiyah Surakarta.

[17] Siregar,H dan Wahyuniarti D. 2012. Dampak Pertumbuhan Ekonomi terhadap Penurunan Jumlah Penduduk Miskin.

[18] Warsilan dan Noor, Akhmad. 2015. Peran Infrastruktur terhadap Pertumbuhan Ekonomi dan Implikasi pada Kebijakan Pembangunan di Kota Samarinda. MIMBAR Jurnal Sosial dan Pembangunan 31 (2) :359. Terakreditasi. 